\title{
PERBANDINGAN NILAI KALOR BIOBRIKET YANG TERBUAT DARI BOTTOM ASH LIMBAH PLTU DAN BIOMASSA CANGKANG KOPI DENGAN VARIASI KOMPOSISI DAN JENIS PENGIKAT YANG BERBEDA
}

\author{
Budi Gunawan*), Sugeng Slamet, Ahmad Syahroni \\ Jurusan Teknik Elektro, Fakultas Teknik, Universitas Muria Kudus, \\ PO BOX 53, Gondang Manis Bae, Kudus
}

\begin{abstract}
Abstrak
Tujuan dari penelitian ini adalah membuat biobriket dari bahan bottom ash limbah Pembangkit Listrik Tenaga Uap (PLTU) dengan biomassa cangkang kopi dengan zat pengikat tetes tebu serta menguji nilai kalor yang dihasilkan. Metode yang digunakan dalam penelitian ini adalah; pembuatan biobriket dengan memvariasi komposisi antara bottom ash dengan biomassanya serta zat pengikat yang berbeda. Variasi komposisi antara biomassa cangkang kopi dengan bootom ash yang digunakan adalah 60\%: 40\% dan 70\%: 30\%, sedangkan bahan perekatnya menggunakan tetes tebu dan tepung kanji. Pengujian yang dilakukan adalah menguji nilai kalor dari biobriket yang dihasilkan menggunakan alat uji calloriboom. Dari hasil pengujian didapatkan biobriket dengan komposisi 70\% biomassa cangkang kopi dan 30\% bottom ash dengan pengikat tetes tebu mempunyai nilai kalor yang paling tinggi dibandingkan dengan komposisi dan pengikat yang lain dengan nilai kalor yang dihasilkan yaitu 2496,18 kal/gr. Nilai kalor ini dipengaruhi oleh kandungan karbon aktif yang terdapat pada arang cangkang kopi dan besar kecilnya kandungan carbon, oxygen dan ash yang dimiliki, semakin tinggi kandungan carbon dan oxygen maka makin tinggi pula nilai kalor yang kandungan kalor yang terdapat pada jenis perekat tetes tebu lebih tinggi dari pada tepung kanji.
\end{abstract}

Kata kunci : bottom ash; biomassa; cangkang kopi; kalor

\begin{abstract}
[Title: Comparison of Calorific Value of Biobriket Made of Bottom Ash Waste and Biomass Plant Shell Coffee by Varying Composition and Types of Binder] This study is aimed to make biobriket of bottom ash material waste biomass power plant and different binder of coffee shell (molasses) as well as measuring the calorific value. The method in this study are by manufacturing biobricket by varying the composition of bottom ash with biomass and different binder. Biomass composition variation of the shell coffee and bottom ash are 60\%:40\% and 70\%:30\%. The binder used are molasses and starch. This experiment was carry out by measuring the calorific value of produced biobricket. From results, the biobricket with a composition of $70 \%$ biomass and $30 \%$ coffee shell bottom ash and molasses binder has the highest calorific value in comparison to other binder composition. The calorific value is $2496.18 \mathrm{cal} / \mathrm{g}$. This calorific value is influenced by the content of activated carbon contained in charcoal shell of coffee and size of the content of carbon, oxygen and ash. Increased calorific values between the molasses and starch binders suggested that the calorific value of product when using molasses binder is higher than that of starch.
\end{abstract}

Keywords : bottom ash; biomass; coffee shells; calorific value

\section{Pendahuluan}

Salah satu penciptaan bahan bakar alternatif melalui program konversi energi yang perlu diupayakan adalah dengan memanfaatkan potensi lokal. Di Kudus ada sebuah pabrik besar yaitu PT. Pura Barutama yang mempunyai unit pembangkit

\footnotetext{
${ }^{*}$ Penulis Korespondensi.

E-mail: budi.gunawan@umk.ac.id
}

mandiri. Pembangkit P.T. Pura Barutama ini menggunakan PLTU yang dalam proses pembakaran batu baranya menyisakan limbah bottom ash yang sementara ini belum termanfaatkan dengan baik bahkan justru menjadi pencemar lingkungan. PLTU PT. Pura Barutama itu bakal menyedot batubara 350 ton/hari, yang tentunya akan banyak menghasilkan limbah bottom ash. Kapasitas limbah batubara buangan sisa pembakaran pada PLTU P.T. Pura Barutama bisa mencapai $\pm 0,5$ ton per hari (Harian 


\section{Teknik, 36 (2), 2015, 82}

Umum Suara Merdeka, n.d.). Di satu sisi di daerah pegunungan Muria yang berlokasi di selatan Kota Kudus merupakan daerah yang banyak menghasilkan kopi. Kopi ini juga mempunyai limbah yaitu cangkangnya yang juga sementara ini belum termanfaatkan dengan baik. Untuk mengatasi permasalahan limbah dari PLTU dan cangkang kopi ini akan dicoba untuk dimanfaatkan sebagai bahan bakar alternatif yang berupa biobriket.

Penelitian yang pernah dilakukan tentang biobriket adalah pengujian laju pembakaran biobriket yang dibuat dari komposisi sabut kelapa dan batubara. Pada penelitian tersebut secara umum disebutkan bahwa laju pembakaran paling cepat diperoleh dari biobriket dengan komposisi 90\% sabut kelapa : 10\% batubara (Sulistyanto, 2006). Hal ini disebabkan, semakin banyak kandungan volatile matter suatu biobriket maka semakin dipengaruhi oleh kandungan volatile matter yang terdapat pada biobriket. Penambahan biomass juga dapat menurunkan emisi polutan yang dihasilkan pada saat pembakaran. (Sulistyanto, 2006). Penelitian yang lain tentang biobriket dilakukan oleh Tri Wijayanti yang telah menguji nilai kalor dari biobriket yang terbuat dari limbah kacang tanah dan kacang mete dengan memvariasi komposisi antara limbah kacang tanah dan limbah kacang mete. Hasil yang terbaik biobriket berbahan campuran limbah kacang tanah dan limbah kacang mete adalah campuran 15 gram arang kulit kacang tanah dan 75 gram arang kulit kacang mete dengan penambahan 30 gram tetes tebu yang menghasilkan nilai kalor sebesar 6551,34 kal/gram. (Wijayanti et al., 2012).

Diantara faktor yang menentukan karakteristik pembakaran suatu briket adalah nilai kalor (Jamilatun, 2012). Dari beberapa referensi penelitian yang telah dilakukan, belum ada yang mencoba membuat dan menguji biobriket yang dibuat dari limbah PLTU beruba bottom ash dengan biomassa cangkang kopi. Melihat potensi lokal yang ada, khususnya kopi di Kabupaten Kudus yang memiliki luas perkebunan kopi seluas 488,83 Ha dengan jumlah produksi sebesar 1.161.192 kg (Potensi Daerah, n.d.), Kabupaten Kudus mempunyai potensi bahan untuk produksi biobriket dari limbah PLTU dan cangkang kopi.

Tujuan dari penelitian ini adalah membuat biobriket dengan memanfaatkan limbah PLTU PT. Pura Barutama yang berupa bottom ash dan potensi lokal yang berupa limbah cangkang kopi dengan beberapa komposisi dan variasi zat pengikat untuk diketahui komposisi mana dan memakai zat pengikat apa yang menghasilkan nilai kalor paling besar.

\section{Metode Penelitian}

Metode penelitian adalah eksperimen dengan membuat biobriket dari limbah PLTU yang berupa bottom ash yang diperoleh dari PLTU PT. Pura Barutama dan biomassa cangkang kopi yang diperoleh dari pegunungan Muria. Variabel pengujian meliputi; perbandingan komposisi biomassa dengan bottom ash dan jenis zat pengikat sebagai variable bebasnya dan nilai kalor dari biobriket yang dihasilkan sebagai variable terikatnya. Data yang digunakan adalah data primer dari hasil pengukuran nilai kalornya menggunakan alat calorimeter. Pengambilan data dilakukan sebanyak 3 kali dan akan diambil data rataratanya.

Perbandingan komposisi yang digunakan ada dua macam, yaitu: (1) $60 \%$ biomassa dan $40 \%$ bottom ash, (2) $70 \%$ biomassa dan 30\% bottom ash. Jenis pengikat yang digunakan adalah tetes tebu dan tepung kanji. Tahapan kegiatan digambarkan pada Gambar 1.

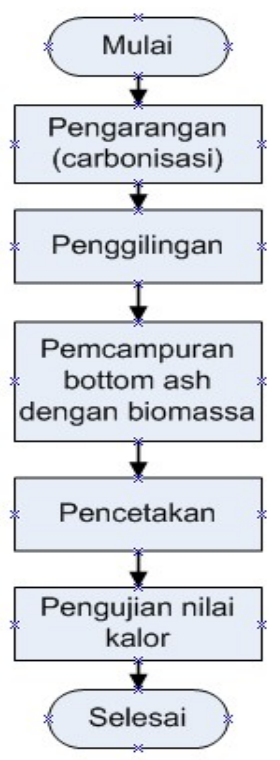

Gambar 1. Tahapan kegiatan penelitian

Proses pengujian nilai kalor yang dilakukan sebagai berikut: 1) sampel briket yang akan diuji (Gambar 1) dihaluskan dan diambil 1 gram, kemudian dimasukan ke dalam combustion capsule, 2) memasang kawat sepanjang $10 \mathrm{~cm}$ ke dalam combustion capsule sampai mengenai serbuk yang akan diuji tanpa mengenai tempat serbuk pada combustion capsule, 3) mengecek kawat menggunakan ampere meter untuk memastikan kawat tersambung antarapositif dan negative, 4) mengisi oksigen ke dalam combustion capsule untuk membantu proses pembakaran, 5) menghubungkan bomb calorimeter dengan listrik, 6) mengisi oval bucket dengan 2 liter air (Gambar 3) dan memasukkan combustion capsuleke dalam oval bucket yang telah terisi air, 7) memasukkan oval bucket ke dalam bomb calorimeter, 8) menunggu sekitar 4 menit hingga suhu yang ada di oval bucket dengan suhu di water jaket mencapai suhu yang sama, setelah suhu sama maka mesin akan secara otomatis mencatat dengan di print out nilai kalor yang terdapat pada bahan dan tertera layar. Biobriket sebanyak 1 gram untuk digunakan sebagai sampel pengujian, dan dimasukkan ke dalam bucket yang sudah dimasukkan ke dalam combustion capsule. 


\section{Teknik, 36 (2), 2015, 83}

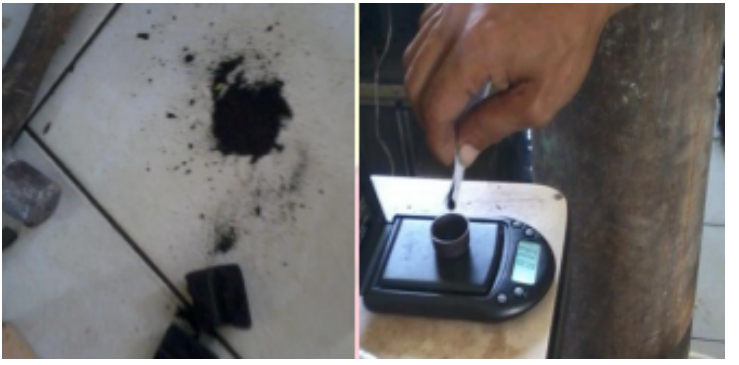

Gambar 2. Sampel biobriket yang akan diuji nilai kalor

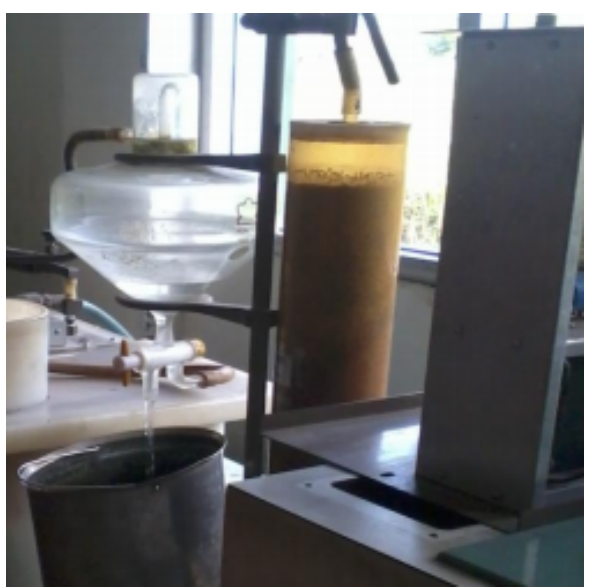

Gambar 3. Mengisi air di oval bucket

Oval bucket yang sudah terisi air dimasukkan dan ditunggu sekitar 4 menit hingga suhu yang ada di oval bucket dengan suhu di water jaket mencapai suhu sama (Gambar 4).

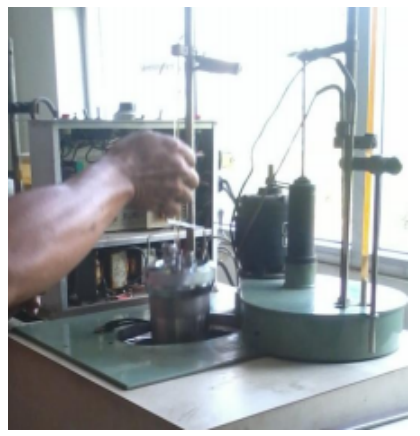

Gambar 4. Memasukkan oval bucket dan tabung reaktor

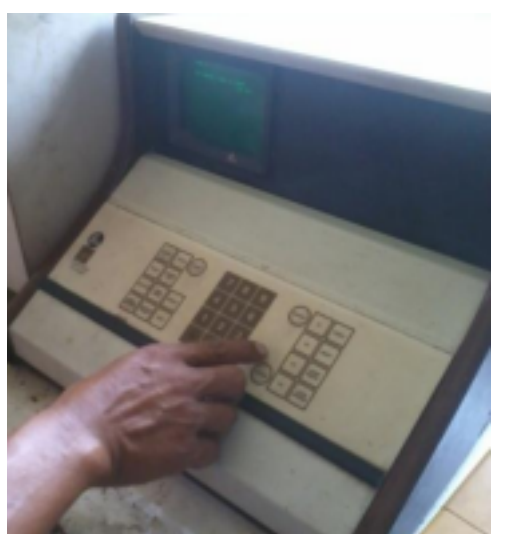

Gambar 5. Monitor yang menampilkan hasil pengujian

\section{Hasil dan Pembahasan}

Setelah diuji menggunakan alat calori boom dengan pengujian sebanyak 5 kali dan diambil nilai kalor rata-ratanya, didapatkan hasil sebagaimana ditunjukkan pada Tabel 1.

Tabel 1. Pengujian nilai kalor

\begin{tabular}{cccc}
\hline $\begin{array}{c}\text { Komposisi biobriket } \\
\text { biomassa - battom ash }\end{array}$ & Pengikat & $\begin{array}{c}\text { Rata-rata } \\
\text { nilai kalor } \\
\text { (kal/gr) }\end{array}$ \\
\hline $60 \%$ & $40 \%$ & Tepung & 1666.33 \\
$70 \%$ & $30 \%$ & kanji & 2243,50 \\
\hline $60 \%$ & $40 \%$ & Tetes tebu & 1928.68 \\
$70 \%$ & $30 \%$ & 2498,27 \\
\hline
\end{tabular}

Berdasarkan tabel pengujian nilai kalor diatas dapat di ketahui bahwa rata-rata nilai kalor tertinggi didapat dari rasio perbandingan $70 \%$ cangkang kopi dan $30 \%$ bottom ash dengan pengikat tetes tebu, yang mempunyai nilai kalor sebesar 2498,27 kal/gr di bandingkan dengan rasio perbandingan $60 \%$ cangkang kopi dan $40 \%$ bottom ash yang mempunyai nilai kalor sebesar 1928,68 kal/gr. Nilai kalor dari perbandingan 60:40 ke 70:30 mengalami kenaikan sebesar 22,8\%. Hal ini dapat terjadi karena biomassa yang terkandung dalam rasio perbandingan $70 \%$ : $30 \%$ lebih banyak sehingga dapat meningkatkan nilai kalor dari briket tersebut. Kandungan kalor bahan perekat menunjukkan bahwa bahan perekat tetes tebu memiliki nilai kalor yang lebih tinggi dibanding dengan kanji. (Ismayana et al., 2012)

\section{Kesimpulan}

Kenaikan nilai kalor cangkang kopi dipengaruhi oleh kandungan karbon aktif yang terdapat pada arang cangkang kopi. Selain hal tersebut, faktor lain yang mempengaruhi besar kecilnya nilai kalor adalah kandungan carbon, oxygen dan ash yang dimiliki. Semakin tinggi kandungan carbon dan oxygen maka makin tinggi pula nilai kalor yang didapat. Terjadi peningkatan nilai kalor antara biobriket dengan perekat tetes tebu dan briket dengan perekat tepung kanji, baik dalam komposisi 70\%-30\% maupun $60 \%-40 \%$. Peningkatan nilai kalor antara perekat tetes tebu dan tepung kanji tersebut disebabkan oleh kandungan kalor yang terdapat pada jenis perekat. Bahan dengan perekat tetes tebu mempunyai nilai kalor yang lebih besar dari pada bahan dengan perekat tepung kanji.

\section{Ucapan Terima Kasih}

Terima kasih disampaikan kepada: 1.) DP2M DIKTI yang telah memberi pendanaan pada penelitian ini dalam skim Hibah Bersaing Tahun 2015 dengan nomor kontrak 008/K6/KM/SP2H/PenelitianBatch$1 / 2015$; 2.) Laboratorium Teknik Mesin Universitas Muria Kudus dan Laboratorium Thermofluida Universitas Diponegoro yang telah memberi fasilitas kegiatan penelitian ini. 


\section{Teknik, 36 (2), 2015, 84}

\section{Daftar Pustaka}

Harian Umum Suara Merdeka (www.suaramerdeka.com/harian/0312/24/dar21 .htm, diaksed pada tanggal 9 Desember 2014).

Ismayana, A., Indrasti, N.S., Suprihatin, A.M., TIP, A.F., other. (2012). Faktor Rasio c/n Awal dan Laju Aerasi Pada Proses Co-Composting Bagasse dan Blotong. Jurnal Teknologi Industri Pertanian, 22.

Jamilatun, S. (2012). Sifat-Sifat Penyalaan dan Pembakaran Briket Biomassa, Briket Batubara, dan Arang Kayu. Jurnal Rekayasa Proses, 2, $37-40$.
Potensi Daerah, n.d., Kabupaten Kudus.

Sulistyanto, A. (2006). Karakteristik Pembakaran Biobriket Batubara dan Sabut Kelapa.

Wijayanti, T., Susila, I.W., et al. (2012). Pembuatan Biobriket dari Campuran Kacang Tanah dan Limbah Kacang Mete Menggunakan Perekat Tetes Tebu. Jurnal Pendidik Teknik Mesin, 1. 